\title{
Effect of integrated diseases management (IDM) modules for the management of stripe rust of wheat
}

\author{
Arshad Husain, S.K. Biswas*», Javed Bahar Khan**, Shivam Kumar and Mohammad Salman*** \\ Department of Plant Pathology, C.S.A. University of Agriculture and Technology, Kanpur-208002, Uttar Pradesh, India \\ *University of Agriculture and Technology, Kanpur-208002, Uttar Pradesh, India \\ **Department of Plant Pathology, C.S.A. University of Agriculture and Technology, Kanpur-208002, Uttar Pradesh, India \\ *** Department of Seed Science and Technology, Acharya Narendra Deva University of Agriculture and Technology, Ayodhya, Uttar Pradesh, \\ India
}

\section{Article Info}

\section{Article history}

Received 17 August 2021

Revised 3 October 2021

Accepted 4 October 2021

Published Online 30 December 2021

\section{Keywords}

Neem extract

Shoot

Disease

Stripe rust

Module

IDM

\begin{abstract}
Wheat (Triticum aestivum L.) is highly affected by stripe rust disease in northern India. Several management practices apply in wheat for the management of wheat rust; however, IDM practices are more effective. They reduced application of fungicide on wheat cultivation. Effect of IDM modules showed maximum shoot length as was recorded in S.A. of Tirchoderma through FYM, S.T. with Azotobactor, 2 Sprays of zinc; $1 \mathrm{st}$ was CRI stage, 2nd was booting stage, representing $(32.05 \mathrm{~cm})$ and $(34.00 \mathrm{~cm})$ and among all the treatments, maximum number of tillers were recorded in S.A. of Tirchoderma through FYM, S.T. with Azotobactor, 2 Sprays of zinc; 1st was CRI stage, 2nd was booting stage, representing (2.89 and 3.00$)$ during 2018-19 and 2019-20, respectively. Among all these treatments, minimum disease severity was recorded in case of S.A. of Tirchoderma through FYM, S.T. with Azotobactor, 2 Sprays of zinc; 1st was CRI stage, 2nd was booting stage, representing (5.33\%) $(9.13 \%)$ and $(3.75 \%)$ at 80 , 90, and 100 days after sowing, respectively during 2018-19. Soil application of Tirchoderma through FYM, seed treatment with Azotobactor, 2 Sprays of zinc; 1st was CRI stage, 2nd was booting stage also more effective against $(81.87 \%)$ disease severity and was decrease over control. In case of disease incidence, minimum disease incidence against yellow rust of wheat was recorded in S.A. of Tirchoderma through FYM, S.T. with Azotobactor, 2 Sprays of zinc; 1st was CRI stage, 2nd was booting stage, representing (13.90\%), (19.10\%) and $(21.21 \%)$ at 80,90 , and 100 days after sowing, respectively during 2019-20.
\end{abstract}

\section{Introduction}

Wheat (Triticum aestivum L.) crop is the important crop belonging to the Family, Graminae and the most important cereal crops produced throughout the world. Wheat is believed to have originated in southwestern Asia (Gibson and Benson, 2002). It is one of the important staple foods in both developed and developing countries. As world population is increasing fast and estimated to reach over 10 billion by 2050 and global insist for food is also increasing, producing additional wheat, is expected to become a high priority (Duveiller et al., 2007; Gupta et al., 2008a). The total production of wheat in the world is about $93,19,66,300$ tons during 2017-18 and India produces about 99,61,008 tons from the 30,60,000 hectare of cultivated land (FAO, 2019-20). Wheat is attacked by several pathogens such as parasitic fungi, viruses, and nematodes and all are able of reducing yield significantly. Among all pathogens, fungi cause major losses and the stripe rusts are the most important diseases of wheat, causing major crop losses globally (Singh et al., 2001). The three Puccinia species of rust fungi in wheat, viz., $P$. recondita $P$. graminis tritici and $P$. striiformis, cause the most

\section{Corresponding author: Dr. S.K. Biswas}

Join Director Research, Department of Plant Pathology, C.S.A. University of Agriculture and Technology, Kanpur-208002, Uttar Pradesh, India

E-mail: samirkrbiswas@ rediffmail.com

Tel.: +91-9140717054

Copyright (C) 2021 Ukaaz Publications. All rights reserved.

Email: ukaaz@yahoo.com; Website: www.ukaazpublications.com destructive diseases affecting wheat all over the world (Boyd, 2005; Kolmer, 2005; Hodson, 2011). Among three Puccinia of wheat, yellow rust and brown rust cause huge loss in northern India (van Ginkel and Rajaram, 1993). The disease occur in all wheat areas of the country and their occurrence depended up on environmental conditions, virulence and susceptibility of host at the time of disease onset (Roelfs et al., 1992; Boyd, 2005). Stripe rust is restricted only in northern parts of the India, particularly in foot hills of Himalayas region. Spores of both, $P$. recondita and $P$. striiformis (yellow rust of wheat) are thought to be primarily dispersed by wind and rainfall, has the potential to spread both brown rust and yellow rust of wheat (Saari et al., 1885). Rust diseases are responsible for massive economics losses in 1972-73, stripe rust which appears in epidemic form in Punjab, Haryana and western U.P., were responsible for a loss of nearly 0.9 to 1.5 million tones of wheat. In 1980, stripe rust epidemic in Uttar Pradesh and parts of Bihar caused a loss of 1 million tones of wheat. A number of strategies are available for the management of stripe rust diseases consisting of cultural, biological control, chemical seed treatment and spray of plant extracts, etc. However, rusts are foliar diseases on a single technique, effectively manage the rust disease like biological control and single use of fungicide method like bavistin, mancozeb and plantvax, causes environmental hazard or carcinogenic to the human; therefore, alternative approach IDM module reduced the risk of chemical and effective control of cereal rust diseases is possible mainly through employment of IDM modules (Brennan and Quade, 2004b). 


\section{Materials and Methods}

\subsection{Collection of stripe rust samples}

A total of 100 stripe rust samples were collected from randomly selected farmers' fields around Kanpur district of Uttar Pradesh. Stripe rust of wheat plants infected with rust pustules and were cut into small pieces of $8-11 \mathrm{~cm}$, using scissors and placed in paper bags. The samples collected from Kanpur district of village Bilhaur (U.P.), India and these samples collected were kept in paper bags and tagged with the name of location and date of collection. The samples within the paper bags were air dried and kept in refrigerator at $12^{\circ} \mathrm{C}$ until the collection in all districts were completed.

\subsection{Multiplication and inoculation}

The inoculum was multiplied and maintained on standard rust susceptible variety "Agra local" which does not carry any stripe rust resistant under polyhouse condition. 55 DAS plants are more suitable for multiplication of stripe rust of wheat or when the primary leaves were fully expanded and the second leaves beginning to grow. Small pieces of leaf sizes of 9-12 cm which are collected from the survey of farmers field have many urediospores of the stripe rust of wheat. These small pieces of leaf mix in the water (8-10 small pieces of leaf for $1000 \mathrm{ml}$ water) methodically, after that sprayed on the "Agra local" cultivar of wheat under polyhouse condition from clean atomizer. For incubation, polyhouse maintain with dew chamber for $20 \mathrm{~h}$ dark period at $18-22^{\circ} \mathrm{C}$, followed by exposure to light for $4 \mathrm{~h}$ and 65-70 relative humidity to provide favorable condition for stripe rust infection. After 10 days of inoculation, symptoms were clearly visible on leaves, containing many urediospores and ready to inoculation to the strong plant with the help of leaf rubbing and atomizer method on pot experiment. Soon after inoculation of stripes rust on healthy plants under pot experiment, were placed in dark condition and transferred to a greenhouse following the earlier method mentioned above or covered with polybag.

\subsection{Treatments}

$\mathrm{T}_{1}$ (Module I ) = Soil application of Tirchoderma harzianum through farm yard manure, seed treatment with Azotobactor, 2 Sprays of zinc; 1 st is crown root initiation stage, 2 nd is booting stage. $\mathrm{T}_{2}$ (Module II ) = Soil application of Azotobactor through spent mashroom substrate, seed treatment with Tirchoderma harzianum, 2 Sprays of propiconazole; 1 st is crown root initiation stage, 2nd is booting stage. $\mathrm{T}_{3}$ (Module III ) = Soil application of Tirchoderma harzianum through vermicompost seed treatment with Tirchoderma harzianum, 2 Sprays of neem extract; 1st is CRI stage, 2nd is booting stage. $\mathrm{T}_{4}$ (Module IV) $=$ Soil application of Azotobactor through vermicompost, seed treatment with Tirchoderma harzianum, 2 Sprays of tabuconazole; 1 st is CRI stage, 2 nd is booting stage. $T_{5}$ $($ Module V) = Soil application of neem cake, seed treatment with Tirchoderma harzianum, 2 Sprays of propiconazole; 1 st is CRI stage, 2nd is booting stage. $\mathrm{T}_{6}$ (Module VI ) = Soil application of Tirchoderma through spent mushroom substrate, seed treatment with tabuconazole, 2 Sprays of neem extract; 1 st is CRI stage, 2 nd is booting stage, $\mathrm{T}_{7}=$ Control (untreated).

\subsection{Measurement of disease severity}

Observations for measuring the disease severity were taken after 60 days, 80 days and 100 days after sowing. 10 leaves were randomly selected from each pot for measurement of disease severity. Observation on disease severity will be recorded using 0-4 scale (McIntosh et al., 1995), The per cent disease severity will be calculated by following formula:

$$
\text { Disease severity percentage }=\frac{\text { Sum of numerical ratings } \times 100 \text { disease }}{\text { Number of plants scored } \times \text { maximum score on scale }}
$$

\begin{tabular}{|c|l|}
\hline Scale & Rating \\
\hline O- & $0-10 \%$ disease \\
$1-$ & $10-20 \%$ disease \\
$2-$ & $20-30 \%$ disease \\
$3-$ & $30-40 \%$ disease \\
$4-$ & $40-50 \%$ \\
$5-$ & $50-100 \%$ \\
\hline
\end{tabular}

\subsection{Measurement of disease incidence}

Observations for measuring the disease incidence were taken after 60 days, 80 days and 100 days after sowing. 12 leaves were randomly selected from each pot for measurement of disease severity, using following formula:

Disease incidence percentage

Total number of infected

$$
=\frac{\text { plant in pot }}{\text { Total number of plant examine }} \times 100
$$

\subsection{Statistical analysis}

The data were analyzed by following the procedure of complete randomized design (CRD) and completely block design (CRD). Data recorded in percentage were first transformed at Arc Sin Value (Fisher and Yates, 1963). Treatments were compared by means of critical difference (CD) at 5 per cent level of significance.

\section{Results}

3.1 Variability significance of different modules on growth parameters of wheat at 80 DAS during 2018-19 and 2019. 2020

Effect of IDM module on shoot length $(\mathrm{cm})$ of wheat after inoculation of yellow rust at 80 DAS was studied under wire house condition in pot culture experiment. The observations of shoot length were taken at 80 days after sowing during 2018-19 and 2019-20. The data presented in Table 1, showed that in both the years, shoot length of wheat was increased in all the treatments over control. The maximum shoot length was recorded in $\mathrm{T}_{1}$ - $\mathrm{S}$.A. of Tirchoderma through FYM, S.T. with Azotobactor, 2 Sprays of zinc; 1st was CRI stage, 2nd was booting stage, representing $(32.05 \mathrm{~cm})$ and $(34.00 \mathrm{~cm})$ during $2018-19$ and 2019-20, respectively. T-S.A. of Tirchoderma through spent mushroom substrate, S.T. with tabuconazole, 2 Sprays of neem extract; 1 st was CRI stage, 2nd 
was booting stage. Shoot length was also increased, representing $(28.30 \mathrm{~cm})$ and $(31.07 \mathrm{~cm})$ during 2018-19 and 2019-20, respectively, followed by $\mathrm{T}_{4}-\mathrm{S}$. A.of Azotobactor through vermicompost, S. T. with Tirchoderma, 2 Sprays of tabuconazole; 1st was CRI stage, $2 \mathrm{nd}$ was booting stage, representing $(27.20 \mathrm{~cm})$ and $(30.60 \mathrm{~cm})$ during $2018-19$ and 2019-20, respectively. $\mathrm{T}_{5}-\mathrm{S} . \mathrm{A}$. of neem cake, S. T. with Tirchoderma, 2 Sprays of propiconazole; 1 st was CRI stage, 2nd was booting stage, representing $(26.50 \mathrm{~cm})$ and $(30.50 \mathrm{~cm})$ during 2018-19 and 2019-20, respectively. The shoot length significantly reduced was recorded in $\mathrm{T}_{7}$-(Control), representing $(22.50 \mathrm{~cm})$ and $(24.30 \mathrm{~cm})$ during 2018-19 and 201920 , respectively. The data presented in Table 1, showed that the root length significantly increased in comparison to all the treatments and control was recorded in $\mathrm{T}_{1}$ - S.A. of Tirchoderma through FYM, S.T. with Azotobactor, 2 Sprays of zinc; 1st was CRI stage, 2nd was booting stage, representing $(14.00 \mathrm{~cm})$ and $(16.50 \mathrm{~cm})$ over control during 2018-19 and 2019-20, respectively (Table 1). After $\mathrm{T}_{1}$, second highest root length was recorded in $\mathrm{T}_{6}$-S.A. of Tirchoderma through spent mushroom substrate, S.T. with tabuconazole, 2 Sprays of neem extract; 1 st was CRI stage, 2nd was booting stage, representing $(11.50 \mathrm{~cm})$ and $(14.80 \mathrm{~cm})$ during 2018-19 and 2019-20, respectively; followed by $\mathrm{T}_{4}$-S.A. of Azotobactor through vermicompost, S.T. with Tirchoderma, 2 Sprays of tabuconazole; 1st was CRI stage, 2nd was booting stage, representing $(11.50 \mathrm{~cm})$ and $(12.60 \mathrm{~cm})$ during $2018-19$ and 2019-20, respectively and $\mathrm{T}_{5}-\mathrm{S}$. A. of neem cake, S.T. with Tirchoderma, 2 Sprays of propiconazole; 1 st is CRI stage, 2nd is booting stage, representing $(09.50 \mathrm{~cm})$ and $(10.50 \mathrm{~cm})$ during 2018-19 and 2019-20, respectively. The minimum root length was recorded in $\mathrm{T}_{7}$-(Control), representing $(07.50 \mathrm{~cm})$ and $(09.50 \mathrm{~cm})$ during 2018-19 and 2019-20, respectively. Table 1 revealed that the maximum fresh weight of shoot was recorded in all the treatments over control, but highest fresh weight of shoot was found in $\mathrm{T}_{1}-\mathrm{S}$. A. of Tirchoderma through FYM, S.T. with Azotobactor, 2 Sprays of zinc; 1st was CRI stage, 2nd was booting stage, representing $5.55(\mathrm{~g})$ and $5.80(\mathrm{~g})$ over control during 2018-19 and 2019-20, respectively. In $\mathrm{T}_{6}$-S.A. of Tirchoderma through spent mushroom substrate, S.T. with tabuconazole, 2 Sprays of neem extract; 1 st was CRI stage, 2nd was booting stage. The second highest fresh weight of shoot was recorded, representing $4.80(\mathrm{~g})$ and $4.89(\mathrm{~g})$ during 2018-19 and 2019-20, respectively, followed by $\mathrm{T}_{4}$-S. A. of Azotobactor through vermicompost, S.T. with Tirchoderma, 2 Sprays of tabuconazole; 1st was CRI stage, 2nd was booting stage, representing $4.29(\mathrm{~g})$ and $4.56(\mathrm{~g})$ during 2018-19 and 2019-20, repectively and $\mathrm{T}_{5}-\mathrm{S}$. A. of neem cake, S. T. with Tirchoderma, 2 Sprays of propiconazole; 1 st was CRI stage, 2nd was booting stage, representing $3.20(\mathrm{~g})$ and $4.40(\mathrm{~g})$ during 2018-19 and 2019-20, respectively. The minimum fresh weight of shoot was recorded in $\mathrm{T}_{7}$ - (Control) in comparison to all treatments, representing 2.16 (g) and $2.00(\mathrm{~g})$ during 2018-19 and 2019-20, respectively. The Table 1 data presented that the fresh weight of root was significantly increased in all the treatments over controls; however, maximum fresh weight of root was found in $\mathrm{T}_{1}$-S.A. of Tirchoderma through FYM, S. T. with Azotobactor, 2 Sprays of zinc; 1st was CRI stage, 2nd was booting stage, representing $1.92(\mathrm{~g})$ and $1.69(\mathrm{~g})$ during 2018-19 and 2019-20, respectively. In $\mathrm{T}_{6}-\mathrm{S}$. A. of Tirchoderma through spent mushroom substrate, S.T. with tabuconazole, 2 Sprays of neem extract; 1st was CRI stage, 2nd was booting stage and there was also significantly increase in fresh weight of root was recorded after $\mathrm{T}_{1}$, representing $1.87(\mathrm{~g})$ and $1.54(\mathrm{~g})$ during 2018-19 and 2019-20, respectively; followed by $\mathrm{T}_{4}$-S.A. of Azotobactor through vermicompost, S. T. with Tirchoderma, 2 Sprays of tabuconazole; 1st was CRI stage, 2nd was booting stage, representing $1.40(\mathrm{~g})$ and $1.25(\mathrm{~g})$ during 201819 and 2019-20, respectively and $\mathrm{T}_{5}$ - S.A. of neem cake, S. T. with Tirchoderma, 2 Sprays of propiconazole; 1st was CRI stage, 2nd was booting stage, representing $1.31(\mathrm{~g})$ and $1.10(\mathrm{~g})$ during 201819 and 2019-20, respectively. In $\mathrm{T}_{7}$-(Control), minimum fresh weight of root was recorded over all treatments representing, 1.00 (g) and 1.01 (g) during 2018-19 and 2019-20, respectively. The data presented in Table 1 was recorded that the $\mathrm{T}_{1}-\mathrm{S}$.A. of Tirchoderma through FYM, S.T. with Azotobactor, 2 Sprays of zinc; 1st was CRI stage, 2nd was booting stage, maximum dry weight of shoot over control, representing $2.31(\mathrm{~g})$ and $2.51(\mathrm{~g})$ during 2018-19 and 2019-20, respectively. Among all treatments, second highest dry weight of shoot was recorded in $\mathrm{T}_{6}-\mathrm{S}$.A. of Tirchoderma through spent mushroom substrate, S.T. with tabuconazole, 2 Sprays of neem extract; 1st was CRI stage, 2nd was booting stage, representing $2.16(\mathrm{~g})$ and $2.40(\mathrm{~g})$ during 201819 and 2019-20, respectively; followed by $\mathrm{T}_{4}-\mathrm{S}$. A. of Azotobactor through vermicompost, S.T. with Tirchoderma, 2 Sprays of tabuconazole; 1 st was CRI stage, 2 nd was booting stage, representing $2.20(\mathrm{~g})$ and $2.10(\mathrm{~g})$ during 2018-19 and 2019-20, respectively and $\mathrm{T}_{5}$-S.A. of neem cake, S.T. with Tirchoderma, 2 Sprays of propiconazole; 1 st was CRI stage, 2nd was booting stage, representing $2.08(\mathrm{~g})$ and $2.13(\mathrm{~g})$ during 2018-19 and 2019-20, respectively. Minimum dry weight of shoot was recorded in $\mathrm{T}_{7}$ (Control) in comparison to all treatments, representing $1.50(\mathrm{~g})$ and 1.10 (g) during 2018-19 and 2019-20, respectively. The Table 1 data show that the maximum dry weight of root was recorded in all the treatments over control; however, among all the treatments, maximum dry weight of root was recorded in $\mathrm{T}_{1}$-S.A. of Tirchoderma through FYM, S. T. with Azotobactor, 2 Sprays of zinc; 1st was CRI stage, 2nd was booting stage, representing 0.98 $(\mathrm{g})$ and $1.60(\mathrm{~g})$ during 2018-19 and 2019-20, respectively. Among all the treatments, second highest dry weight of root was found in $\mathrm{T}_{6}-\mathrm{S}$. A. of Tirchoderma through spent mushroom substrate, S. T. with tabuconazole, 2 Sprays of neem extract; 1st was CRI stage, 2nd was booting stage, representing $0.90(\mathrm{~g})$ and $1.42(\mathrm{~g})$ during 2018-19 and 2019-20, respectively; followed by $\mathrm{T}_{4}$-S.A. of Azotobactor through vermicompost, S.T. with Tirchoderma, 2 Sprays of tabuconazole; 1st was CRI stage, 2nd was booting stage, representing $0.78(\mathrm{~g})$ and $1.31(\mathrm{~g})$ during 2018-19 and 201920, respectively and $\mathrm{T}_{5}$ - S.A. of neem cake, S.T. with Tirchoderma, 2 Sprays of propiconazole; 1st was CRI stage, 2nd was booting stage, representing $0.70(\mathrm{~g})$ and $1.10(\mathrm{~g})$ during 2018-19 and 201920 , respectively. In $\mathrm{T}_{7}$-(Control), in comparison to all treatments, show minimum dry weight of root, representing, $0.60(\mathrm{~g})$ and 0.70 (g) during 2018-19 and 2019-20, respectively. The data recorded in Table 1 show maximum number of tillers recorded in all the treatments in both the years over control, but among the all treatments, maximum number of tillers were recorded in $\mathrm{T}_{1}-\mathrm{S}$. A. of Tirchoderma through FYM, S. T. with Azotobactor, 2 Sprays of zinc; 1st was CRI stage, 2nd was booting stage, representing 2.89 and 3.00 during 2018-19 and 2019-20, respectively. After $\mathrm{T}_{1}$, the second highest number of tillers were recorded in $\mathrm{T}_{6}$-S.A. of Tirchoderma through spent mushroom substrate, S.T. with tabuconazole, 2 Sprays of neem extract; 1 st was CRI stage, 2nd 
was booting stage, representing 2.66 and 2.89 during 2018-19 and 2019-20, respectively, followed by $\mathrm{T}_{4}$ - S.A. of Azotobactor through vermicompost, S. T. with Tirchoderma, 2 Sprays of tabuconazole; 1st was CRI stage, 2nd was booting stage, representing 2.54 and 2.45 during 2018-19 and 2019-20, respectively and $\mathrm{T}_{5}$-S.A. of neem cake, S. T. with Tirchoderma, 2 Sprays of propiconazole; $1 \mathrm{st}$ was CRI stage, 2 nd was booting stage, representing 2.32 and 2.23 (g) during 2018-19 and 2019-20, respectively. Minimum number of tillers were recorded in $\mathrm{T}_{7}$-(Control) in comparison to all treatments, representing 1.43 and 1.76 during 2018-19 and 201920 , respectively.

Table 1: Effect of IDM module on plant growth parameters of wheat after inoculation of yellow rust at 80 DAS (Wire house condition) during 2018-19 to 2019-20

\begin{tabular}{|c|c|c|c|c|c|c|c|c|c|c|c|c|c|c|}
\hline \multirow[t]{3}{*}{ Treatment } & \multicolumn{6}{|c|}{ 2018-19 } & & \multicolumn{6}{|c|}{ 2019-20 } & \multirow{3}{*}{$\begin{array}{l}\text { No. of } \\
\text { tillers }\end{array}$} \\
\hline & \multicolumn{2}{|c|}{$\begin{array}{c}\text { Plant } \\
\text { length }(\mathrm{cm} .)\end{array}$} & \multicolumn{2}{|c|}{$\begin{array}{c}\text { Fresh } \\
\text { weight (g) }\end{array}$} & \multicolumn{2}{|c|}{$\begin{array}{c}\text { Dry } \\
\text { weight }(\mathrm{g})\end{array}$} & \multirow[t]{2}{*}{$\begin{array}{l}\text { No. of } \\
\text { tillers }\end{array}$} & \multicolumn{2}{|c|}{$\begin{array}{c}\text { Plant } \\
\text { length }(\mathrm{cm} .)\end{array}$} & \multicolumn{2}{|c|}{$\begin{array}{c}\text { Fresh } \\
\text { weight (g) }\end{array}$} & \multicolumn{2}{|c|}{$\begin{array}{c}\text { Dry } \\
\text { weight }(g)\end{array}$} & \\
\hline & Shoot & Root & Shoot & Root & Shoot & Root & & Shoot & Root & Shoot & Root & Shoot & Root & \\
\hline $\mathrm{T}_{1}$ & 32.05 & 14.00 & 5.55 & 1.92 & 2.31 & 0.98 & 2.89 & 34.00 & 16.50 & 5.80 & 1.69 & 2.51 & 1.60 & 3.00 \\
\hline $\mathrm{T}_{2}$ & 24.40 & 8.14 & 3.15 & 1.29 & 1.80 & 0.86 & 1.63 & 25.90 & 11.70 & 3.28 & 1.08 & 2.00 & 1.00 & 1.88 \\
\hline $\mathrm{T}_{3}$ & 25.10 & 10.10 & 3.58 & 1.20 & 2.02 & 0.66 & 2.00 & 27.01 & 12.10 & 5.50 & 1.11 & 2.10 & 1.10 & 2.03 \\
\hline $\mathrm{T}_{4}$ & 27.20 & 11.50 & 4.29 & 1.40 & 2.20 & 0.78 & 2.54 & 30.60 & 12.60 & 4.56 & 1.25 & 2.10 & 1.31 & 2.45 \\
\hline $\mathrm{T}_{5}$ & 26.50 & 09.50 & 3.20 & 1.31 & 2.08 & 0.70 & 2.32 & 30.50 & 10.50 & 4.40 & 1.10 & 2.13 & 1.10 & 2.23 \\
\hline $\mathrm{T}_{6}$ & 28.30 & 11.50 & 4.80 & 1.87 & 2.16 & 0.90 & 2.66 & 31.07 & 14.80 & 4.89 & 1.54 & 2.40 & 1.42 & 2.89 \\
\hline$\left(\right.$ Control $\left.\mathrm{T}_{7}\right)$ & 22.50 & 07.50 & 2.16 & 1.00 & 1.50 & 0.60 & 1.43 & 24.30 & 09.50 & 2.00 & 1.01 & 1.10 & 0.70 & 1.76 \\
\hline $\mathrm{SE}(\mathrm{m})$ & 0.496 & 0.478 & 0.185 & 0.034 & 0.046 & 0.024 & 0.072 & 0.621 & 0.717 & 0.214 & 0.046 & 0.069 & 0.037 & 0.119 \\
\hline $\mathrm{SE}(\mathrm{d})$ & 0.701 & 0.676 & 0.262 & 0.049 & 0.066 & 0.034 & 0.102 & 0.878 & 1.013 & 0.303 & 0.066 & 0.097 & 0.052 & 0.168 \\
\hline $\mathrm{CD}$ at $5 \%$ & 1.437 & 1.385 & 0.536 & 0103 & 0.138 & 0.069 & 0.207 & 1.801 & 2.078 & 0.623 & 0.138 & 0.202 & 0.107 & 0.346 \\
\hline
\end{tabular}

Mean of 5 replications $*$ DAS $=$ Day after sowing.

Table 2: Effect of IDM module on disease severity of wheat inoculation of yellow rust at different days interval (Wire house condition) during 2018-19 to 2019-20

\begin{tabular}{|c|c|c|c|c|c|c|c|c|}
\hline \multirow[t]{2}{*}{ Treatments } & \multicolumn{4}{|c|}{ 2018-19\% Disease severity/pot } & \multicolumn{4}{|c|}{$2019-20 \%$ Disease severity/pot } \\
\hline & 80 DAS & 90 DAS & 100 DAS & $\begin{array}{c}\% \text { Disease } \\
\text { severity } \\
\text { decrease } \\
\text { over control }\end{array}$ & 80 DAS & 90 DAS & 100 DAS & $\begin{array}{l}\text { \% Disease } \\
\text { severity } \\
\text { decrease } \\
\text { over control }\end{array}$ \\
\hline $\mathrm{T}_{1}$ & 05.33 & 09.13 & 13.75 & 83.96 & 07.19 & 10.52 & 15.87 & 81.87 \\
\hline $\mathrm{T}_{2}$ & 14.67 & 30.56 & 56.78 & 33.76 & 17.10 & 33.98 & 59.56 & 31.97 \\
\hline $\mathrm{T}_{3}$ & 08.10 & 14.33 & 20.45 & 76.14 & 09.81 & 15.28 & 21.89 & 75.00 \\
\hline $\mathrm{T}_{4}$ & 09.66 & 15.89 & 22.78 & 73.42 & 09.98 & 16.10 & 23.90 & 72.70 \\
\hline $\mathrm{T}_{5}$ & 08.19 & 17.90 & 21.00 & 75.50 & 08.78 & 18.01 & 22.16 & 74.69 \\
\hline $\mathrm{T}_{6}$ & 07.89 & 12.76 & 16.89 & 80.29 & 08.98 & 13.12 & 17.34 & 80.19 \\
\hline (Control) $\mathrm{T}_{7}$ & 16.78 & 45.69 & 85.73 & - & 19.27 & 44.19 & 87.56 & - \\
\hline $\mathrm{SE}(\mathrm{m})$ & 0.6739 & 0.8367 & 1.1952 & & 0.8678 & 0.9562 & 1.5538 & \\
\hline $\mathrm{SE}(\mathrm{d})$ & 0.9530 & 0.1830 & 1.6901 & & 1.2270 & 1.3521 & 2.1970 & \\
\hline $\mathrm{CD}$ at $5 \%$ & 2.0780 & 0.4244 & 3.4635 & & 2.5144 & 2.7708 & 4.5024 & \\
\hline
\end{tabular}

Mean of 5 replications $* \mathrm{DAS}=$ Day after sowing. 
Table 3: Effect of IDM module on disease incidence of wheat inoculation with yellow rust at different days interval (Wire house condition) during 2018-19 to $2019-20$

\begin{tabular}{|c|c|c|c|c|c|c|c|c|}
\hline \multirow[t]{2}{*}{ Treatments } & \multicolumn{4}{|c|}{ 2018-19\% Disease severity/pot } & \multicolumn{4}{|c|}{ 2019-20\% Disease severity/pot } \\
\hline & 80 DAS & 90 DAS & $100 \mathrm{DAS}$ & $\begin{array}{c}\% \text { Disease } \\
\text { severity } \\
\text { decrease } \\
\text { over control }\end{array}$ & 80 DAS & 90 DAS & 100 DAS & $\begin{array}{l}\% \text { Disease } \\
\text { severity } \\
\text { decrease } \\
\text { over control }\end{array}$ \\
\hline $\mathrm{T}_{1}$ & 13.19 & 17.29 & 20.10 & 77.44 & 13.90 & 19.10 & 21.21 & 76.68 \\
\hline $\mathrm{T}_{2}$ & 27.18 & 36.23 & 61.08 & 31.44 & 29.97 & 40.20 & 69.34 & 23.79 \\
\hline $\mathrm{T}_{3}$ & 22.65 & 29.67 & 30.89 & 65.33 & 23.90 & 31.54 & 34.20 & 62.41 \\
\hline $\mathrm{T}_{4}$ & 18.54 & 24.80 & 26.21 & 70.58 & 19.78 & 26.29 & 30.11 & 66.90 \\
\hline $\mathrm{T}_{5}$ & 20.45 & 27.87 & 29.10 & 67.34 & 22.22 & 29.76 & 32.98 & 63.75 \\
\hline $\mathrm{T}_{6}$ & 14.76 & 18.21 & 22.23 & 75.05 & 13.29 & 17.97 & 24.17 & 73.43 \\
\hline (Control) $\mathrm{T}_{7}$ & 40.19 & 70.34 & 89.10 & - & 43.25 & 75.92 & 90.99 & - \\
\hline SE (m) & 1.1116 & 1.4343 & 2.3905 & & 1.2962 & 1.7928 & 2.9880 & \\
\hline $\mathrm{SE}(\mathrm{d})$ & 1.5718 & 2.0281 & 3.3801 & & 1.8329 & 2.5350 & 4.2251 & \\
\hline $\mathrm{CD}$ at $5 \%$ & 3.2209 & 4.1561 & 6.9268 & & 3.7560 & 5.1951 & 8.6584 & \\
\hline
\end{tabular}

Mean of 5 replications $*$ DAS $=$ Day after sowing.

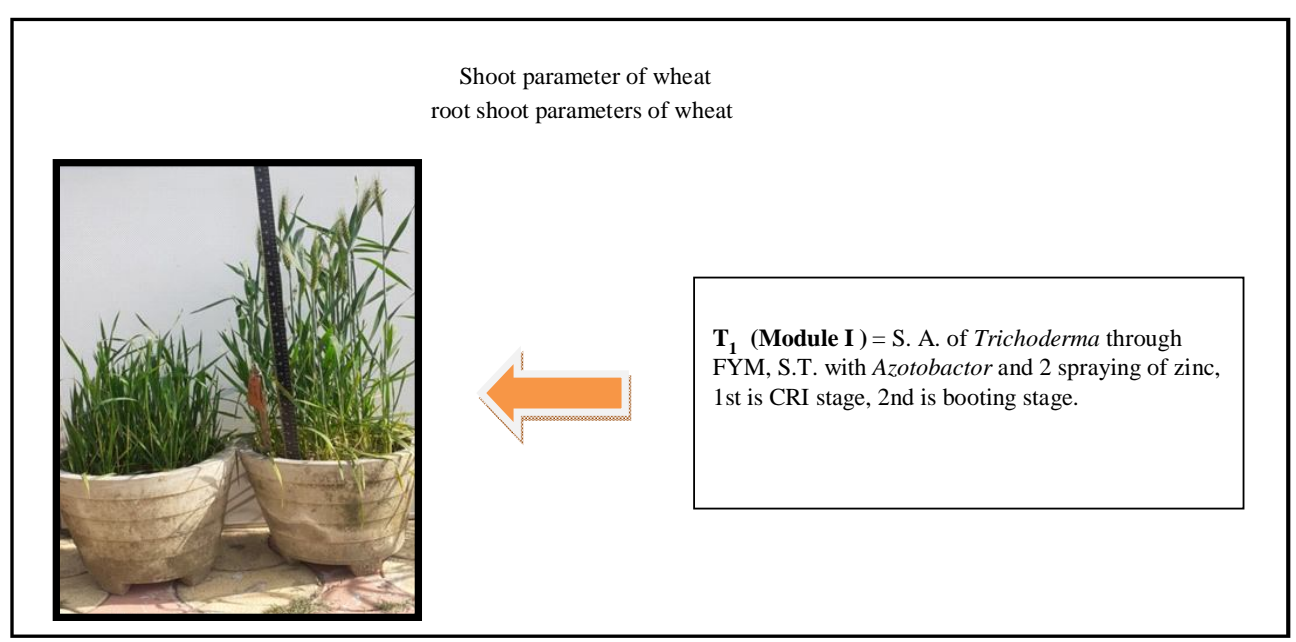

$\mathbf{T}_{2}$ (Module II $)=$ S. A. of Azotobactor through SMS, S.T. with Trichoderma and 2 spraying of propiconazole, 1 st is CRI stage, 2nd is booting stage.

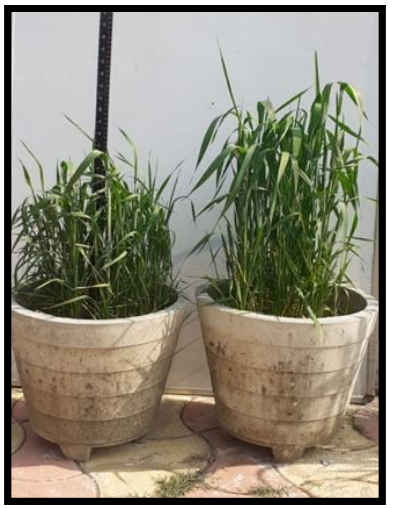



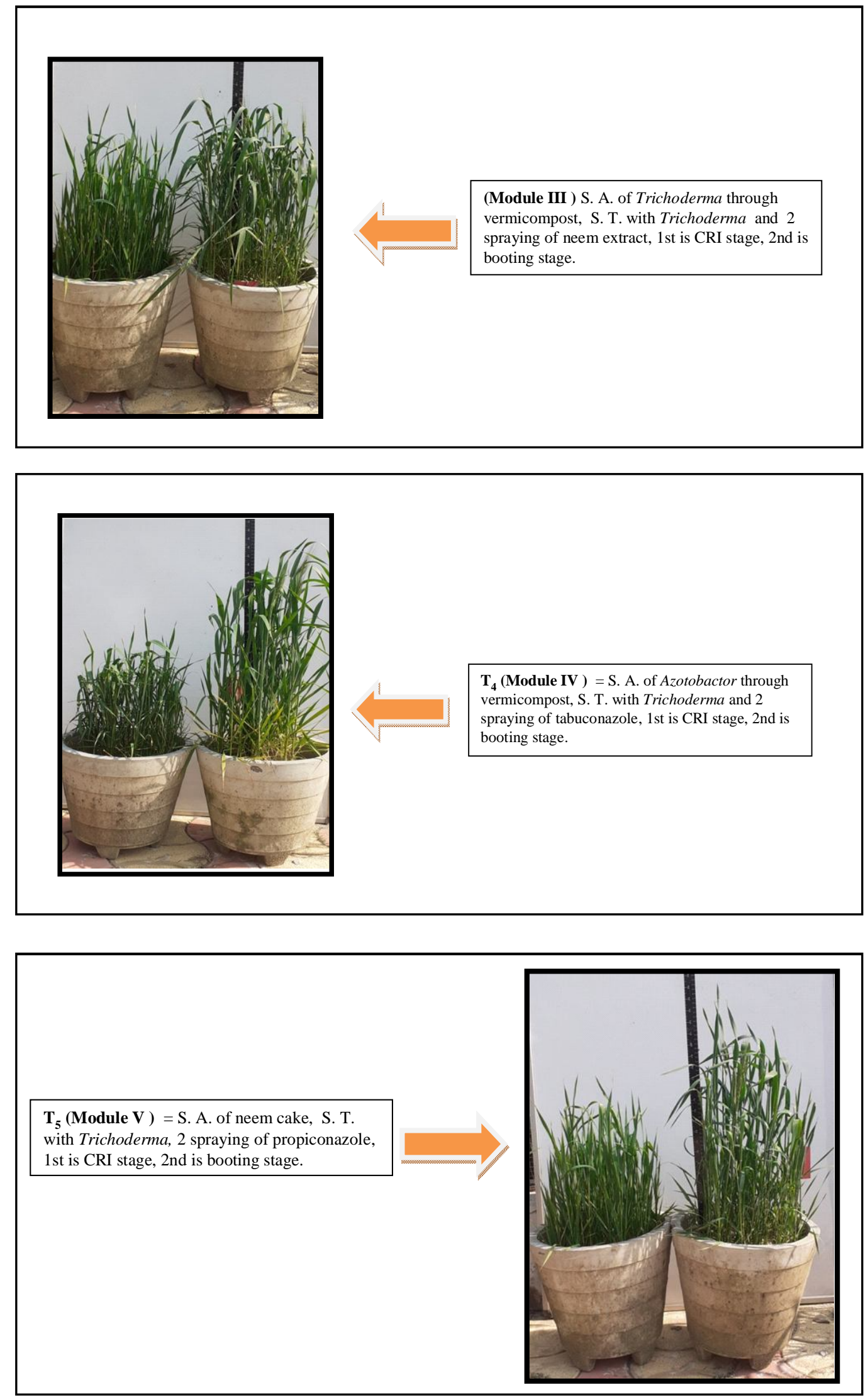

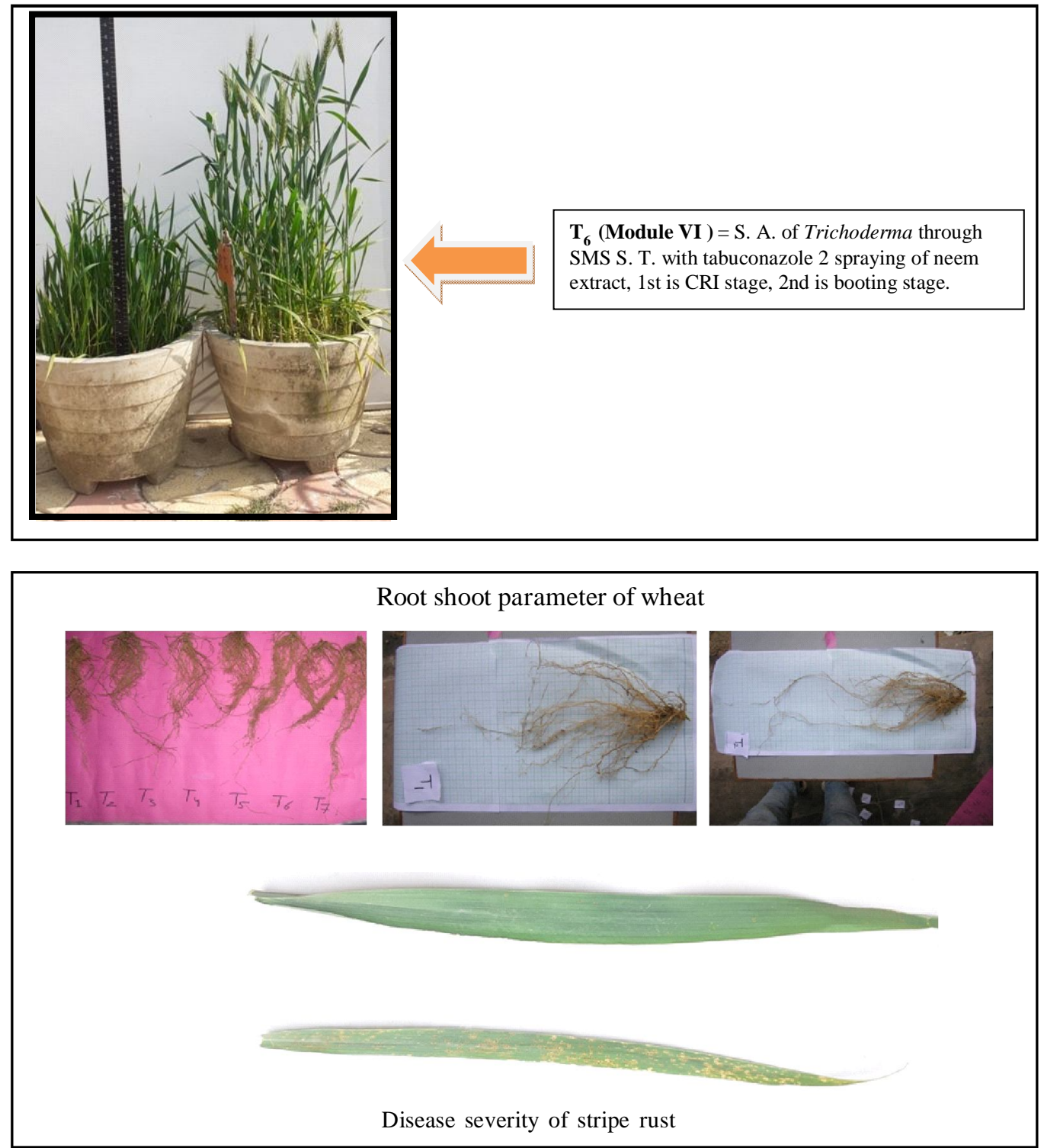

3.2 Variability significance of different modules on disease severity and incidence of yellow rust of wheat at different days of interval during 2018-19 to 2019-2020

The data presented in Table 2 showed that all the treatments significantly reduced disease severity of yellow rust of wheat as compared to control. However, among all the treatments, minimum disease severity was recorded in case of $\mathrm{T}_{1}$-S.A. of Tirchoderma through FYM, S.T. with Azotobactor, 2 Sprays of zinc; 1st was CRI, stage 2nd was booting stage, representing 05.33\%, 09.13\% and $13.75 \%$ at 80,90 , and 100 days after sowing, respectively during 2018-19. Second lowest disease severity of yellow rust of wheat was recorded in $\mathrm{T}_{6}$-S.A. of Tirchoderma through spent mushroom substrate, S.T. with tabuconazole, 2 Sprays of neem extract; 1st was CRI stage, 2nd was booting stage, representing $07.89 \%, 12.76 \%$ and $16.89 \%$ at 80,90 , and 100 days after sowing, respectively during 2018-19; followed by $\mathrm{T}_{4}$ - S.A. of Azotobactor through vermicompost, S.T. with Tirchoderma, 2 Sprays of tabuconazole; 1st was CRI stage, 2nd was booting stage, representing
$09.66 \%, 15.89 \%$ and $22.78 \%$ at 80,90 , and 100 days after sowing, respectively during 2018-19 and $\mathrm{T}_{5}$-S.A. of neem cake, S.T. with Tirchoderma, 2 Sprays of propiconazole; 1st was CRI stage, 2nd was booting stage, representing $08.19 \%, 17.90 \%$ and $21.00 \%$ at 80, 90, and 100 days after sowing, respectively during 2018-19. Highest disease severity was recorded in $\mathrm{T}_{7}$ - (Control), representing $16.78 \%, 45.69 \%$ and $85.73 \%$ at 80,90 , and 100 days after sowing, respectively during 2018-19. Percentage of highest decrease disease severity was found in $T_{1} 83.96 \%$ over control. Second highest decrease disease severity was recorded in $\mathrm{T}_{6} 80.29 \%$; followed by $\mathrm{T}_{4} 73.42 \%$ and $\mathrm{T}_{5} 75.50 \%$ over control during 2018-19. The data presented in Table 2 showed that the disease severity of yellow rust of wheat in all treatments significan-tly reduced over control. However, among all the treatments, minimum disease severity was recorded in case of $\mathrm{T}_{1}$-S.A. of Tirchoderma through FYM, S.T. with Azotobactor, 2 Sprays of zinc; 1st was CRI stage, 2nd was booting stage, representing $07.19 \%, 10.52 \%$ and $15.87 \%$ at 80,90 , and 100 days after sowing respectively during 2019-20. After $\mathrm{T}_{1}$, 
second minimum disease severity of yellow rust of wheat was recorded in $\mathrm{T}_{6}-\mathrm{S}$.A. of Tirchoderma through spent mushroom substrate, S.T. with tabuconazole, 2 Sprays of neem extract; 1 st was CRI stage, 2nd was booting stage, representing $08.98 \%, 13.12 \%$ and $17.34 \%$ at 80,90 , and 100 days after sowing, respectively during 2019-20; followed by $\mathrm{T}_{4}-\mathrm{S}$.A. of Azotobactor through vermicompost, S. T. with Tirchoderma, 2 Sprays of tabuconazole; 1st was CRI stage, 2nd was booting stage, representing $09.98 \%$, $16.10 \%$ and $23.90 \%$ at 80,90 and 100 days after sowing, respectively during 2019-20 and $\mathrm{T}_{5}$-S.A. of neem cake, S.T. with Tirchoderma, 2 Sprays of propiconazole; 1st was CRI stage, 2nd was booting stage, representing $08.78 \%, 18.01 \%$ and $22.16 \%$ at 80,90 , and 100 days after sowing, respectively during 2019-20. Among all the treatments, maximum disease severity was recorded in $\mathrm{T}_{7}$-(Control), representing $19.27 \%, 44.19 \%$ and $87.56 \%$ at 80,90 , and 100 days after sowing, respectively during 2019-20. Among all the treatments, $\mathrm{T}_{1}$ was more effective against and showed $81.87 \%$ disease severity over control. Second highest decrease disease severity was found in $\mathrm{T}_{6}(74.69 \%)$ over control, followed by $\mathrm{T}_{4}(72.70 \%)$ and $\mathrm{T}_{5}(74.69 \%)$ over control during 2019-20. The data presented in Table 3 showed that the disease incidence of yellow rust of wheat significantly reduced in all treatments over control. However, among all the treatments, minimum disease incidence was found in $\mathrm{T}_{1}$ S.A. of Tirchoderma through FYM, S.T. with Azotobactor, 2 Sprays of zinc; 1st was CRI stage, 2nd was booting stage, representing $13.19 \%, 17.29 \%$ and $20.10 \%$ at 80,90 , and 100 days after sowing, respectively during 2018-19. Among all the treatments, second effective treatment and lowest disease incidence of yellow rust of wheat was recorded in $\mathrm{T}_{6}$-S.A. of Tirchoderma through spent mushroom substrate, S.T. with tabuconazole; 2 Sprays of neem extract; 1 st was CRI stage, 2nd was booting stage, representing $14.76 \%, 18.21 \%$ and $22.23 \%$ at 80,90 , and 100 days after sowing, respectively during 2018-19; followed by $\mathrm{T}_{4}$ - S.A. of Azotobactor through vermicompost; S.T. with Tirchoderma, 2 Sprays of tabuconazole; 1 st was CRI stage, 2 nd aws booting stage, representing $18.54 \%, 24.80 \%$ and $26.21 \%$ at 80,90 , and 100 days after sowing, respectively during 2018-19 and $\mathrm{T}_{5}-\mathrm{S}$. A. of neem cake, $\mathrm{S}$. T. with Tirchoderma, 2 Sprays of propiconazole; 1st was CRI stage, 2nd was booting stage, representing $20.45 \%, 27.87 \%$ and $29.10 \%$ at 80, 90, and 100 days after sowing, respectively during 2018-19. $\mathrm{T}_{7}$ - (Control) was not much effective against yellow rust of wheat; therefore, highest disease incidence was recorded in $\mathrm{T}_{7^{-}}$(Control), representing $40.19 \%, 70.34 \%$ and $89.10 \%$ at 80,90 , and 100 days after sowing, respectively during 2018-19. More effective treatment and maximum disease incidence was recorded in $\mathrm{T}_{1}(77.44 \%)$ over control. Second highest disease incidence in $\mathrm{T}_{6}(75.05 \%)$ over control, followed by $\mathrm{T}_{4}(70.58 \%)$ and $\mathrm{T}_{5}(67.34 \%)$ over control during 2018-19. The data presented in Table 3 showed that the disease incidence of yellow rust of wheat significantly reduced in all treatments over control. However, among all the treatments, highly effective and minimum disease incidence against yellow rust of wheat was recorded in $\mathrm{T}_{1}$-S. A. of Tirchoderma through FYM, S. T. with Azotobactor, 2 Sprays of zinc; 1st was CRI stage, 2nd was booting stage, representing $13.90 \%, 19.10 \%$ and $21.21 \%$ at 80,90 , and 100 days after sowing, respectively during 2019-20. Among all the treatments, second more effective treatment and minimum disease incidence of yellow rust of wheat was found in $T_{6}-S$. A. of Tirchoderma through spent mushroom substrate, S.T. with tabuconazole, 2 Sprays of neem extract; 1st was CRI stage, 2nd was booting stage, representing $13.29 \%, 19.10 \%$ and $21.21 \%$ at 80, 90, and 100 days after sowing, respectively during 2019-20; followed by $\mathrm{T}_{4}-\mathrm{S}$. A. of Azotobactor through vermicompost, $\mathrm{S}$. T. with Tirchoderma, 2 Sprays of tabuconazole; 1st was CRI stage, 2nd was booting stage, representing $19.78 \%, 26.29 \%$ and $30.11 \%$ 80,90 , and 100 days after sowing, respectively during 2019-20 and $\mathrm{T}_{5}$-S.A. of neem cake, S.T. with Tirchoderma, 2 Sprays of propiconazole; 1st was CRI stage, 2nd was booting stage, representing $22.22 \%, 29.76 \%$ and $32.98 \%$ at 80,90 , and 100 days after sowing, respectively during 2019-20. Highest disease severity was recorded in $\mathrm{T}_{7}$-(Control), representing $(43.25 \%),(75.92 \%)$ and $(90.99 \%)$ at 80,90 , and 100 days after sowing, respectively during 2019-20. Per cent of highest decrease disease incidence against yellow rust of wheat was recorded in $\mathrm{T}_{1}(76.68 \%)$ over control. However, second highest decrease disease incidence was found in $\mathrm{T}_{6}(76.68 \%)$ over control, followed by $\mathrm{T}_{4}(66.90 \%)$ and $\mathrm{T}_{5}(63.75 \%)$ over control during 2018-19 (Table 3).

\section{Discussion}

IDM combining several method for the management of major diseases of wheat, the use of seed treatment, soil application of FYM and foliar application of neem seed extract (Singh and Rajaram, 1992a; McIntosh, 1992b). It can be defined as a decision-based process involving coordinated use of multiple tactics for optimizing the control of the pathogen ecologically and economically (Khokhar and Gupta, 2014). A investigation concluded that the fungicides propiconazole, with bioagents $T$. harzianum and botanicals (neem leaf extract and neem cake extract) in two season experiments were found to be effective in reducing the disease incidence, severity of brown and yellow rusts of wheat and increasing grain yield (Yadav et al., 2015). Inoculation of bioagent increased wheat shoot fresh weight by $16.2 \%-53.8 \%$, leaf area increases by $6.0 \%-47.0 \%$ and increased plant height by $2.2 \%-24.6 \%$ and $1.9 \%-36.8 \%$ in wheat (Cakmakcý et al., 2007). Seed treatment with bioagent which reduces disease severity and increase growth parameter should be done after treating the seeds with bioagent $T$. harzianum viride @ $4.0 \mathrm{~g} /$ $\mathrm{kg}$ seeds plus tebuconazole 2 DS (raxil) @ $0.1 \mathrm{~g} / \mathrm{kg}$ of seeds (Goates and Jackson, 2006). It was found that seed treatment with fungicide plantvax@2.5 g/kg of seeds and use of balanced NPK fertilizers and spraying of plants with dithane M 45 @ 0.2\% or propiconazole or tebuconazole @ 0.1\% at 25-35 days interval starting from the first symptoms appearance in the field also reduced disease incidence and severity of wheat leaf rust (Ahanger et al., 2014). Reported that sowing of seeds should be done after treating the seeds with bioagent $T$. harzianum viride @ $4.0 \mathrm{~g} / \mathrm{kg}$ seeds plus tebuconazole 2 DS (raxil) @ $0.1 \mathrm{~g} / \mathrm{kg}$ of seeds give excellent control of all three rust of wheat. Similarly, effect find out by Mehta, (2004) æS IDM combining cultural, physical, chemical and biological methods for the management of wheat rust; the use of seed treatment, soil application of FYM and foliar application of neem seed extract. Application of fungicide solution of propiconazole and tebuconazole is recommended to control the yellow rust, but among these fungicides propiconazole (tilt) which gives excellent control of yellow rusts and is most effective when applied prior to infection (Eddy, 2009). A investigation concluded that the fungicides, propiconazole, carbendazim, tabuconazole with bioagents $T$. harzianum and botanicals (neem leaf extract and neem cake extract) in two season experiments were found to be effective in reducing the disease incidence, severity of brown and yellow 
rusts of wheat and increasing grain yield (Kumar et al., 2021; Chakraborty et. al., 2021) reported that some secondary metabolites derived from $T$. harzianum inhibit mycelial growth, and conidial germination and produced morphological modifications in the germinated conidia, suppression of the several wheat diseases. Simon et al. (2021) found that effectiveness of different fungicides and biocontrol agent to control Puccinia striiformis reduced the disease severity in wheat against stripe rust

\section{Acknowledgements}

This study was supported by my Ph.D. guide, Professor S.K. Biswas, Professor and a Director Research at C. S. A. University of Agriculture and Technology, Kanpur, Uttar Pradesh, India and also to my senior, Dr. Kishan Lal and batchmate, Shivam Kumar who help me for the conducting this research work for two years.

\section{Conflict of interest}

The authors declare no conflicts of interest related to this article.

\section{References}

Ahanger, R. A.; Gupta, V.; Bhat, H. A. and Dar, N. A. (2014). Management of yellow rust (Puccinia striiformis West) of wheat and its impact on yield under Jammu subtropics of India. The Bioscan, 9: 215-218

Boyd, L.A. (2005). Can robigus defeat an old enemy yellow rust of wheat. Journal of Agricultural Science Cambridge, 143:233.

Bray, H.C. and Thorpe, W.V. (2010). Analysis of phenolic compound of interest in metabolism. Plant Biochem., 1:27-52.

Brennan, J.P. and Quade, K.J. (2004a). Analysis of the impact of CIMMYT research on the Australian wheat industry, Economic Research Report 25. NSW Department of Primary Industries, Wagga Wagga, Australia, 1:27-52.

Çakmakḉ, R., Erat, M., Erdoðan, Ü. and Dönmez, M.F. (2007). The influence of plant growth-promoting rhizobacteria on growth and enzyme activities in wheat and spinach plants. Journal of Plant Nutrition and Soil Science, 170(2):288-295.

Duveiller, E.; Singh, R. P. and Nicol, J. M. (2007). The challenges of maintaining wheat productivity: Pests, diseases, and potential epidemics. Euphytica, 157:417-430

Eddy, R. (2009). Logistic regression models to predict stripe rust infections on wheat and yield response to foliar fungicide application on wheat in Kansas. M.Sc. Thesis, B.S. Kansas State University, Manhattan, Kansas.

FAOSTAT, F. (2017-18). Agriculture Organization of the United Nations. Statistical Database. http://faostat.fao.org (accessed November 10, 2013).
Gibson, L. and Benson, G. (2002) Origin, history, and uses of oat (Avena sativa) and wheat (Triticum aestivum). Iowa State University, $\mathrm{pp}: 23$

Goates, B. J. and Jackson, E.W. (2006). Susceptibility of wheat to Tilletia indica during stages of spike development. phytopathology, 96(9):962-966.

Gupta, P.; Balyan, H.; Edwards, K.; Isaac, P.; Korzun, V.; Röder, M.; Gautier, M.; F.; Joudrier P.; Schlatter A. and Dubcovsky, J. (2002). Genetic mapping of 66 new microsatellite (SSR) loci in bread wheat. Theor. Appl. Genet., 105:413-422.

Hodson, D.P. (2011). Shifting boundaries: Challenges for rust monitoring. Euphytica, 179:93-104.

Kalappanavar, I.K.; Patidar, RK. and Kulkarni, S. (2008). Management strategies of leaf rust of Wheat caused by Puccinia recondita f. sp. tritici Rob. ex. Desm Karnataka Journal of Agricultural Sciences, 21(1):35-42.

Kolmer, J.A. (1996). Genetics of resistance to wheat leaf rust. Annu. Rev. Phytopathol., 34:435-455.

Kumar, S.; Kumar, N.; Prajapati, S. and Maurya, S. (2020). Review on spot blotch of wheat: An emerging threat to wheat basket in changing climate. Journal of Pharmacognosy and Phytochemistry, 9(2):1985-1997.

Khokhar, K. M. and Gupta, R. (2014). Integrated Disease Management. Pop. Kheti, 2(1):87-91.

Mehta, Y.R. (2014). Wheat diseases and their management (Vol. 256). Switzerland: Springer.

Roelfs, A.P.; Singh, R.P. and Saari, E.E. (1992). Rust diseases of wheat: Concepts and methods of disease management. CIMMYT, Mexico., pp:1-81.

Saari, E.E. and Prescott, J.M. (1985). World distribution in relation to economic losses. In diseases, distribution, epidemiology, and control pp:259-298. Academic Press.

Stackman, R.W. (1962). Hippocampal spatial representations require vestibular input. Hippocampus, 12(3):291-303.

Singh, D.; Park, R. F. and McIntosh, R. A. (2001). Postulation of leaf (brown) rust resistance genes in 70 wheat cultivars grown in the United Kingdom. Euphytica, 120:205-218.

Yadav, D.; Shavrukov, Y.; Bazanova, N.; Chirkova, L.; Borisjuk, N.; Kovalchuk, N. and Lopato, S. (2015). Constitutive overexpression of the TaNFYB4 gene in transgenic wheat significantly improves grain yield. Journal of Experimental Botany, 66(21):6635-6650.

Van Ginkel, M. and Rajaram, S. (1993). Breeding for durable resistance to diseases in wheat: An additional perspective. In: Jacobes T, Parlevliet J.E. (eds) Durability of disease resistance. Kluwer Academic Publishers, Dordrecht, Netherlands, pp:259-227.

Arshad Husain, S.K. Biswas, Javed Bahar Khan, Shivam Kumar and Mohammad Salman (2021). Effect of 